\title{
Increased RANKL expression in peripheral $T$ cells is associated with decreased bone mineral density in patients with COPD
}

\author{
YING CHEN $^{1}$, PENG BAI $^{1}$, LILI LIU ${ }^{1}$, JUNYAN HAN $^{2}$, HUI ZENG $^{2}$ and YONGCHANG SUN ${ }^{1,3}$ \\ ${ }^{1}$ Department of Respiratory Medicine, Beijing Tongren Hospital, Capital Medical University, Beijing 100730; \\ ${ }^{2}$ Institute of Infectious Diseases, Beijing Ditan Hospital, Capital Medical University, Beijing 100015; \\ ${ }^{3}$ Department of Respiratory Medicine, Peking University Third Hospital, Beijing 100191, P.R. China
}

Received January 5, 2016; Accepted May 20, 2016

DOI: $10.3892 /$ ijmm.2016.2629

\begin{abstract}
Receptor activator of nuclear factor- $\mathrm{\kappa B}$ ligand (RANKL)-expressing adaptive $\mathrm{T}$ cells contribute to bone damage in autoimmune arthritis, although their role in chronic obstructive pulmonary disease (COPD)-associated osteoporosis is unknown. In the present study, the functional expression of RANKL in $\mathrm{CD}^{+} / \mathrm{CD} 8^{+} \mathrm{T}$ cells and Th17 cells, and the potential role of these cells in COPD-associated bone loss was investigated. A total of 36 non-smokers, 38 smokers with normal lung function and 57 patients with COPD were enrolled. Femoral and vertebral bone mineral density (BMD) was assessed by dual energy X-ray absorptiometry. RANKL expression in peripheral $\mathrm{CD}^{+}$and $\mathrm{CD} 8^{+} \mathrm{T}$ cells and Th17 cells was evaluated by flow cytometry. For in vitro experiments, $\mathrm{CD} 4^{+}$and $\mathrm{CD} 8^{+} \mathrm{T}$ cells from 17 non-smokers were evaluated for RANKL expression following dose-dependent culture with cigarette smoke extract (CSE) for 5 days. The frequencies of RANKL-positive $\mathrm{CD} 4^{+}$and $\mathrm{CD} 8^{+} \mathrm{T}$ cells were higher in the patients with COPD than in the non-smokers $(\mathrm{P}=0.001$ and $\mathrm{P}=0.002$, respectively). The proportion of $\mathrm{CD}^{+} \mathrm{T}$ cells positive for both RANKL and interleukin-17 (IL-17) was higher in the patients with COPD than in the non-smokers $(\mathrm{P}=0.010)$. However, the frequency of RANKL-expressing Th17 cells was similar among all groups $(\mathrm{P}=0.508)$. The frequency of $\mathrm{RANKL}^{+} \mathrm{CD} 4^{+} \mathrm{T}$ cells inversely correlated with BMD of the lumbar vertebrae $(\mathrm{P}=0.01, \mathrm{r}=-0.229)$, and that of the femoral neck $(\mathrm{P}<0.001, \mathrm{r}=-0.350)$. The results of our in vitro experiments revealed that CSE increased RANKL expression in
\end{abstract}

Correspondence to: Dr Hui Zeng, Institute of Infectious Diseases, Beijing Ditan Hospital, Capital Medical University, 8 East Jingshun Street, Chaoyang, Beijing 100015, P.R. China

E-mail: zenghui@ccmu.edu.cn

Dr Yongchang Sun, Department of Respiratory Medicine, Beijing Tongren Hospital, Capital Medical University, 1 Dongjiaominxiang, Dongcheng, Beijing 100730, P.R. China

E-mail: suny@ccmu.edu.cn

Key words: chronic obstructive pulmonary disease, osteoporosis, $\mathrm{CD}^{+} \mathrm{T}$ cells, Th17 cells, $\mathrm{CD}^{+} \mathrm{T}$ cells, receptor activator of nuclear factor- $\kappa \mathrm{B}$ ligand
$\mathrm{CD}^{+}{ }^{+} \mathrm{T}$ cells only. The percentages of RANKL-positive $\mathrm{CD}^{+} \mathrm{T}$ cells and RANKL- and IL-17 double-positive $\mathrm{CD}^{+} \mathrm{T}$ cells were increased in the peripheral blood of patients with COPD, and the former were associated with BMD. These observations suggest that $\mathrm{RANKL}^{+} \mathrm{CD} 4^{+} \mathrm{T}$ cells may be mechanistically linked to diseases of the lung and bone in patients with COPD.

\section{Introduction}

Chronic obstructive pulmonary disease (COPD) is mainly a disease of the lungs; however, systemic involvement is a characteristic of the disease. The Global Strategy for the Diagnosis, Managment and Prevention of COPD, by the Global Initiative for Chronic Obstructive Lung Disease (GOLD) emphasizes that COPD usually co-exists with other diseases, and that these comorbidities have a significant effect on the disease manifestations and prognosis of patients with COPD (1).

Osteoporosis is one of the most important comorbidities of COPD, and patients with COPD co-presenting with osteoporosis have a higher risk of developing fractures, and this significantly increases both the disease burden and morbidity associated with COPD. It has been shown that the bone mineral density (BMD) of patients with COPD is lower than that of the apparently normal healthy population $(2,3)$, and more importantly, there is a significant correlation between osteoporosis and the severity of COPD, including emphysema (4), which suggests that there may be some common mechanism or combination of mechanisms involved. Systemic inflammation in COPD is considered to play a role in the pathogenesis of osteoporosis (5); however, the underlying cellular and molecular mechanisms remain to be elucidated.

The bone metabolic regulatory system of osteoprotegerin (OPG)/receptor activator of nuclear factor- $\kappa \mathrm{B}$ (RANK)/receptor activator of nuclear factor- $\kappa B$ ligand (RANKL) plays a key role in the balance of bone destruction and formation. RANK, the receptor of RANKL, is located on the surface of the precursor cells of osteoclasts and mature osteoclasts (6). RANKL induces the differentiation of precursor cells into mature osteoclasts, promotes mature osteoclast activation and suppresses osteoclast apoptosis (7). Mature osteoclasts excrete hydrochloric acid and proteolytic enzymes, which leads to increased bone absorption, osteopenia and osteoporosis (8). 
In our previous study, we demonstrated that soluble RANKL (sRANKL) levels and the ratio of sRANKL/OPG in the peripheral blood of patients with COPD and osteoporosis were higher than those from patients with COPD without osteoporosis and healthy non-smokers. In addition, there was a negative correlation between the level of sRANKL and BMD in patients with COPD (9). A recent study revealed that the serum OPG level was significantly higher in patients with COPD with a normal BMD than in those presenting with osteopenia or osteoporosis; moreover, the serum OPG level independently predicted hip BMD in patients with COPD (10). These results suggest that disturbances in the OPG/RANK/RANKL system may be involved in bone loss in COPD.

Studies on osteoimmunity have found that activated lymphocytes express RANKL. In chronic inflammation, activated lymphocytes produce RANKL, which binds to RANK and promotes osteoclast differentiation and maturity (11). Previously, Kong et al reported that activated $\mathrm{T}$ cells produced two types of RANKL, sRANKL and membrane-bound RANKL (mRANKL), both of which induce osteoclast differentiation and maturity (12). Kotake et al found that activated RANKL-expressing T cells directly induce the differentiation of peripheral blood mononuclear cells (PBMCs) into osteoclasts (13). It was also previously demonstrated that in patients with rheumatoid arthritis (RA), peripheral $\mathrm{CD}^{+}$and $\mathrm{CD}^{+} \mathrm{T}$ cells expressed higher levels of RANKL as compared to healthy subjects, and the percentage of RANKL ${ }^{+} \mathrm{CD}^{+} \mathrm{T}$ cells was higher than that of RANKL ${ }^{+} \mathrm{CD}^{+} \mathrm{T}$ cells (14). It has also been shown that among $\mathrm{CD} 4^{+} \mathrm{T}$ cells, Th17 cells express higher levels of RANKL than their Th1 and Th2 counterparts (15). In vitro experiments confirmed that Th17 cells, rather than Th1 and Th2 cells, played the role of specific T helper cells in bone destruction (15). The study by Kikuta et al confirmed that RANKL-expressing Th17 cells had immediate contact with osteoclasts, and induced bone absorption by osteoclasts (16).

Accumulating evidence has suggested that $\mathrm{CD}^{+}{ }^{+}$and $\mathrm{CD}^{+} \mathrm{T}$ cells, and more recently $\mathrm{Th} 17$ cells, play an important role in inflammation and emphysema that is characteristic of COPD (17-19). However, whether these cells participate in bone absorption, thus linking the disease of the lungs and the bones in COPD, remains unexplored. Thus, in this study, using flow cytometry, we analyzed the distribution of RANKL-expressing $\mathrm{T}$ cells $\left(\mathrm{CD} 4^{+} \mathrm{T}\right.$ cells, $\mathrm{CD}^{+} \mathrm{T}$ cells and Th17 cells) in the blood of patients with COPD, and the correlation between RANKLexpressing $\mathrm{T}$ cells and the severity of bone destruction in COPD. Finally, in an in vitro model, we examined the effects of cigarette smoke extract (CSE) on the proliferation and differentiation of RANKL-expressing T cells.

\section{Materials and methods}

Study subjects. A total of 57 male patients with COPD and 38 male smokers with normal lung function were recruited in this study. In addition, 36 male healthy non-smokers were recruited as the normal controls. Female patients were excluded from this study in order to avoid the influence of postmenopausal osteoporosis. Informed consent was signed by each subject prior to enrollment, and the local research ethics Committee approved this study (TRECKT 2008-14). The baseline characteristics of the study subjects are summarized in Table I.
The diagnosis of COPD was carried out in accordance with the GOLD criteria (20). Patients with COPD had a FEV1/FVC ratio $<70 \%$ of the predicted value post-bronchodilator. All patients with COPD were clinically stable without deterioration for the preceding 3 months.

Smokers with normal lung functions had a smoking history with a smoking index $\geq 200$ and a FEV1/FVC ratio $>70 \%$ and an FEV1 $>80 \%$ of the predicted value. The normal controls were non-smokers with normal lung functions.

The exclusion criteria for the 3 groups were as follows: i) other chronic pulmonary diseases such as asthma, bronchiectasis and interstitial lung diseases, among others; ii) a history of surgery of the lungs or the chest; iii) cancer; iv) autoimmune diseases; v) use of systemic immunosuppressive agents or corticosteroid; vi) acute infections such as respiratory and urinary tract infections; vii) diseases or therapies that can affect bone metabolism.

Measurement of BMD. BMD of the lumbar spine (L1-L4) and the bilateral femoral neck was measured by dual X-ray absorptiometry (Lunar Prodigy, GE Healthcare, London, UK). $\mathrm{BMD}$ is reported as a $\mathrm{T}$ score, which represents the number of standard deviations from a young, gender and ethnic group specific reference mean.

Cell collection. Five milliliters of peripheral blood were collected in an EDTA-treated tube from each subject and were processed to measure the PBMCs for flow cytometry. Fifty microliters of blood were used to measure the absolute count and the subpopulations of $\mathrm{T}$ lymphocytes. The blood samples were then layered onto Ficoll-Paque Plus (Amersham Biosciences, Bucks, UK), centrifuged (400 x g for $20 \mathrm{~min}$ ) and the PBMCs were harvested. The cells were washed twice in phosphate-buffered saline (PBS) at $300 \mathrm{x}$ g for $5 \mathrm{~min}$. The PBMCs were resuspended at a density of $10^{6}$ cells $/ \mathrm{ml}$ in RPMI-1640 medium (10\% fetal bovine serum, $1 \%$ penicillin-streptomycin double-resistant), and stimulated with PMA at $25 \mu \mathrm{g} / \mathrm{l}$, and supplemented with ionomycin $1 \mathrm{mg} / \mathrm{l}$, brefeldin $10 \mathrm{mg} / \mathrm{l}$ and Golgi blockers $0.7 \mu \mathrm{l} / \mathrm{ml}$; (eBioscience, San Diego, CA, USA), and then cultured for $5 \mathrm{~h}$ in an incubator at $\mathrm{CO}_{2}$ at $37^{\circ} \mathrm{C}$.

Flow cytometry. Following incubation, the PBMCs were stained with anti-CD4-APC (23-3153-02), anti-CD8-FITC (23-2327-04) (both from BD Biosciences, Oxford, UK) and anti-CD254 (RANKL)-PE (12-6619-82; e-Bioscience, San Diego, CA, USA) antibodies. Following perforation of the cytomembrane with a 'Fix and Perm' kit (e-Bioscience), fluorescence staining with an interleukin (IL)-17 monoclonal antibody (anti-IL-17-percp; BD Biosciences) was performed as previously described (21). Corresponding isotypic controls were used as staining controls (BD Biosciences and e-Bioscience). We analyzed the original data with a FACSCalibur (BD Biosciences) flow cytometer using FlowJo software (Tree Star, Inc., Ashland, OR, USA).

Effect of CSE on RANKL and IL-17 expression in T cells. CSE was prepared as previously described with some modifications (22). Commercially filtered cigarettes (Hongtashan; Yuxi Cigarette Factory, Yuxi, China) which contained $13 \mathrm{mg}$ of tar and $1.2 \mathrm{mg}$ of nicotine/cigarette were used. CSE was diluted in RPMI-1640 medium to various concentrations and 
Table I. Demographic characteristics of the study populations.

\begin{tabular}{lcccc}
\hline Characteristic & $\begin{array}{c}\text { Non-smokers } \\
(\mathrm{n}=36)\end{array}$ & $\begin{array}{c}\text { Smokers } \\
(\mathrm{n}=38)\end{array}$ & $\begin{array}{c}\text { COPD patients } \\
(\mathrm{n}=57)\end{array}$ & $\begin{array}{c}\text { P-value among } \\
\text { the 3 groups }\end{array}$ \\
\hline Age (years) & $74.00 \pm 9.49$ & $72.44 \pm 12.27$ & $77.70 \pm 10.89$ & $\mathrm{P}=0.059$ \\
Smoking index & 0 & $488.33(325-600)$ & $698.72(400-900)$ & $\mathrm{P}=0.025$ \\
FEV1/FVC\% & $80.15 \pm 6.39$ & $77.99 \pm 5.06$ & $53.15 \pm 11.31$ & $\mathrm{P}<0.001$ \\
FEV1\% pred & $94.24 \pm 13.80$ & $90.06 \pm 12.81$ & $61.93 \pm 21.11$ & $\mathrm{P}<0.001$ \\
T score of lumbar spine & $1.72 \pm 1.62$ & $0.57 \pm 1.33$ & $0.30 \pm 1.95$ & $\mathrm{P}<0.001$ \\
T score of femoral neck & $0.01 \pm 1.10$ & $-0.22 \pm 1.21$ & $-0.87 \pm 1.16$ & $\mathrm{P}=0.001$ \\
\hline
\end{tabular}

Data are presented as the median and interquartile range for the smoking index, and as the means \pm SD for all other parameters. FEV $1 \%$ pred and FEV1/FVC were post-bronchodilator values. COPD, chronic obstructive pulmonary disease.

the final concentrations of the solution were expressed as percentage values (CSE solution volume/total volume) x100. The concentrations of $1,1.5$ and $2 \%$ were selected according to preliminary experimental results. In addition, another 17 healthy non-smoking volunteers with normal lung functions were recruited, who did not belong to the 36-person control group. Thirty milliliters of peripheral blood were collected in EDTA-treated tubes from each subject. The PBMCs were isolated from peripheral blood and resuspended in RPMI-1640 medium. $\mathrm{CD}^{+}$and $\mathrm{CD}^{+} \mathrm{T}$ cells were purified using immunomagnetic beads (Miltenyi Biotech, Bergisch-Gladbach, Germany) and cultured for 5 days.

The $\mathrm{CD}^{+}$and $\mathrm{CD}^{+} \mathrm{T}$ cells from each volunteer were divided into 4 groups as follows: CSE 0, 1, 1.5 and $2 \%$. CD3/28 antibody (16-0037-85, 16-0289-85; e-Bioscience) was used in all the groups. Following culture for 5 days, both the $\mathrm{CD}^{+}$and $\mathrm{CD}^{+} \mathrm{T}$ cells were resuspended at a density of $10^{6}$ cells $/ \mathrm{ml}$ in RPMI-1640 medium. The CD4 ${ }^{+} \mathrm{T}$ cells were stained with anti-CD4-APC (23-3153-02; BD Biosciences) and anti-CD254-PE (12-6619-82; e-Bioscience), and the $\mathrm{CD}^{+} \mathrm{T}$ cells were stained with anti-CD8-FITC (23-2327-04; BD Biosciences) and anti-CD254-PE (12-6619-82; e-Bioscience) antibodies. The expression levels of RANKL on T cells were analyzed by FlowJo software.

To examine the effects of CSE on IL-17 expression, $\mathrm{CD} 4^{+} \mathrm{T}$ cells from each volunteer were divided into 4 groups: CSE $0,1,1.5$ and $2 \%$. CD3/28 antibody was used in all groups. Cytokines [transforming growth factor (TGF)- $\beta 3 \mathrm{ng}$ / $\mathrm{ml}$, IL-1 $\beta 10 \mathrm{ng} / \mathrm{ml}$, IL-6 $100 \mathrm{ng} / \mathrm{ml}$ and IL-23 $10 \mathrm{ng} / \mathrm{ml}$; all from PeproTech, Rocky Hill, NJ, USA] that were required for Th17 cell differentiation were also added. Following culture for 5 days, the $\mathrm{CD}^{+} \mathrm{T}$ cells were resuspended at $10^{6}$ cells $/ \mathrm{ml}$ in RPMI-1640 medium and were then stimulated with PMA for $5 \mathrm{~h}$ at $37^{\circ} \mathrm{C}$ in an incubator at $\mathrm{CO}_{2}$. Following incubation, the $\mathrm{CD}^{+} \mathrm{T}$ cells were stained with anti-CD4-APC, and then following perforation of the cytomembrane with a 'Fix and Perm' kit, fluorescence staining with anti-IL-17-PerCP was performed for each group of $\mathrm{CD}^{+} \mathrm{T}$ cells. The expression levels of IL-17 in T cells were analyzed by FlowJo software.

Data analysis. Group data are expressed as the means \pm SEM or as the median and interquartile range where appropriate. For data that was distributed normally, comparisons among 3 groups were made using one-way ANOVA ( $\mathrm{P}<0.05$ was considered significant). If this test indicated significance, the Bonferroni test was used for post-hoc analysis for comparison between 2 groups $(\mathrm{P}<0.05$ was considered significant). For data not distributed normally, comparisons among groups were made using one-way Kruskal-Wallis test $(\mathrm{P}<0.05$ was considered significant). If this test indicated significance, the Mann-Whitney test was used for post-hoc analysis for comparison between 2 groups $(\mathrm{P}<0.017$ was considered significant). Correlation analysis was assessed by calculating Spearman's rank correlation coefficient. A value of $\mathrm{P}<0.05$ was considered to indicate a statistically significant difference. To examine the effects of CSE on RANKL and IL-17 expression in T cells, the differences among the 4 groups of $\mathrm{CD}^{+} \mathrm{T}$ cell and $\mathrm{CD} 8^{+} \mathrm{T}$ cell cultures were analyzed using random block design analysis of variance (an $\alpha$ value of $\mathrm{P}<0.05$ was considered significant). Statistical analysis was performed using the SPSS version 16.0 statistical software package.

\section{Results}

Demographic characteristics of the study population. The characteristics of the patients with COPD, smokers and the healthy control subjects are summarized in Table I. All the subjects were males, and there were no significant differences among the groups in terms of age. The patients with COPD exhibited a markedly reduced value of the predicted FEV $1 \%$. In addition, the patients with COPD had significantly decreased $\mathrm{T}$ scores of the lumbar spine and the femoral neck as compared to the healthy non-smokers (Fig. 1).

RANKL expression levels in T cells $\left(C D 4^{+} T\right.$ cells, $C D 8^{+} T$ cells and Th17 cells) among non-smokers, smokers and patients with $C O P D$. We analyzed the absolute number and the percentage of total $\mathrm{T}$ lymphocytes, $\mathrm{CD}^{+}$and $\mathrm{CD}^{+} \mathrm{T}$ cells in the peripheral blood by flow cytometry (Table II), and by doing so, determined no significant differences among the 3 groups. Consistent with previous findings (29), we found a higher percentage of Th17 cells (IL-17 ${ }^{+} \mathrm{CD} 4^{+} \mathrm{T}$ cell \%) in the patients with COPD than in non-smokers $(\mathrm{P}<0.001)$ (Table III).

We then investigated the percentages of $\mathrm{RANKL}^{+}$cells in different $\mathrm{T}$ cell subpopulations. As shown in Figs. 2 and 3 and Table III, the patients with COPD exhibited a higher percentage of $\mathrm{RANKL}^{+} \mathrm{CD} 4^{+} \mathrm{T}$ cells $(\mathrm{P}=0.001)$ and a higher percentage 
A

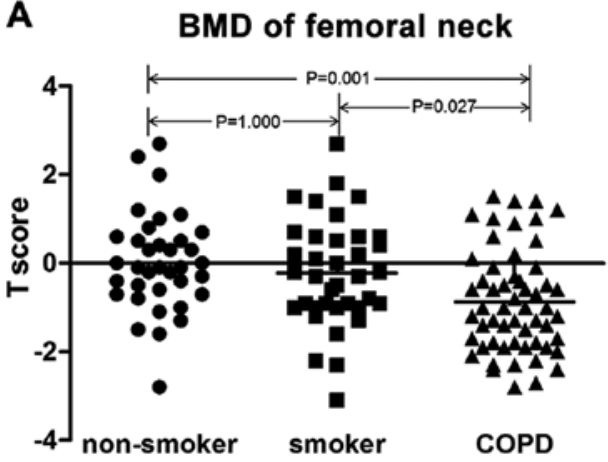

B BMD of lumbar vertebrae

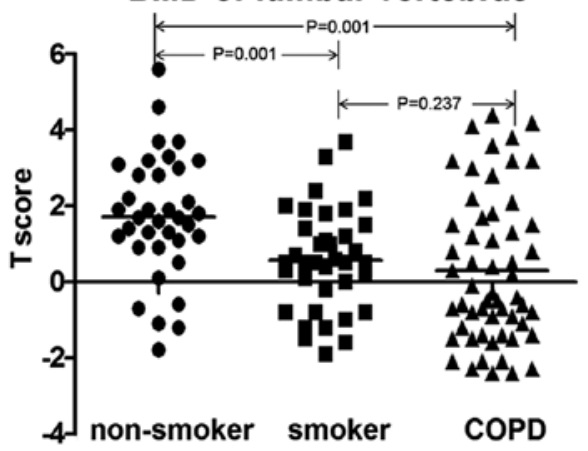

Figure 1. Bone mineral density (BMD) of non-smokers, smokers and patients with chronic obstructive pulmonary disease (COPD) . (A) T scores of the femoral neck. (B) T scores of the lumbar vertebrae. A P-value $<0.05$ was considered to indicate a statistically significant difference.

Table II. Number and percentage of peripheral T lymphocytes and their subpopulations.

\begin{tabular}{lcccc}
\hline Cell subset & $\begin{array}{c}\text { Non-smokers } \\
(\mathrm{n}=36)\end{array}$ & $\begin{array}{c}\text { Smokers } \\
(\mathrm{n}=38)\end{array}$ & $\begin{array}{c}\text { COPD patients } \\
(\mathrm{n}=57)\end{array}$ & $\begin{array}{c}\text { P-value among } \\
\text { the 3 groups }\end{array}$ \\
\hline $\mathrm{CD} 3 \mathrm{ab}(\mathrm{cells} / \mu \mathrm{l})$ & $1105.89 \pm 381.42$ & $1348.24 \pm 490.79$ & $1236.41 \pm 602.68$ & 0.122 \\
$\mathrm{CD} 3(\%)$ & $68.32 \pm 8.68$ & $69.68 \pm 8.13$ & $70.23 \pm 10.06$ & 0.137 \\
$\mathrm{CD} 4 \mathrm{ab}(\mathrm{cells} / \mu 1)$ & $653.35 \pm 242.12$ & $814.08 \pm 330.63$ & $723.78 \pm 428.91$ & 0.139 \\
$\mathrm{CD} 4(\%)$ & $40.46 \pm 8.43$ & $41.86 \pm 7.69$ & $41.46 \pm 10.59$ & 0.789 \\
$\mathrm{CD} 8 \mathrm{ab}(\mathrm{cells} / \mu 1)$ & $383.76 \pm 163.08$ & $478.08 \pm 203.36$ & $534.00 \pm 496.83$ & 0.137 \\
$\mathrm{CD} 8(\%)$ & $23.70 \pm 6.47$ & $25.14 \pm 8.10$ & $25.22 \pm 6.89$ & 0.588 \\
\hline
\end{tabular}

Data are presented as the means $\pm \mathrm{SD}$. COPD, chronic obstructive pulmonary disease.

Table III. RANKL ${ }^{+} \mathrm{T}$ cell subsets in the peripheral blood of the study populations.

\begin{tabular}{|c|c|c|c|c|}
\hline Cell subset & $\begin{array}{l}\text { Non-smokers } \\
\quad(n=36)\end{array}$ & $\begin{array}{c}\text { Smokers } \\
(\mathrm{n}=38)\end{array}$ & $\begin{array}{l}\text { COPD patients } \\
\quad(\mathrm{n}=57)\end{array}$ & $\begin{array}{l}\text { P-value among } \\
\text { the } 3 \text { groups }\end{array}$ \\
\hline $\mathrm{RANKL}^{+} \mathrm{CD} 4^{+} \mathrm{T}$ cell $(\%)$ & $1.04 \pm 0.55$ & $1.66 \pm 1.18$ & $1.96 \pm 1.25$ & 0.003 \\
\hline $\mathrm{RANKL}^{+} \mathrm{CD}^{+} \mathrm{T}$ cell $(\%)$ & $0.91(0.45-1.14)$ & $1.17(0.44-1.62)$ & $1.55(0.61-2.16)$ & 0.006 \\
\hline $\mathrm{RANKL}^{+} \mathrm{IL}-17^{+} \mathrm{CD} 4^{+} \mathrm{T}$ cell $(\%)$ & $0.08(0.04-0.12)$ & $0.11(0.04-0.15)$ & $0.15(0.06-0.17)$ & 0.037 \\
\hline $\mathrm{IL}-17^{+} \mathrm{CD} 4^{+} \mathrm{T}$ cell $(\%)$ & $0.95 \pm 0.44$ & $1.17 \pm 0.53$ & $1.5 \pm 0.71$ & $<0.001$ \\
\hline $\mathrm{RANKL}^{+} \mathrm{Th} 17(\%)$ & $8.31 \pm 5.11$ & $9.61 \pm 6.82$ & $10.6 \pm 7.88$ & 0.508 \\
\hline
\end{tabular}

Data are presented as the median and interquartile range for $\mathrm{CD}^{+} \mathrm{RANKL}{ }^{+}(\%)$ and $\mathrm{CD} 4{ }^{+} \mathrm{IL}-17^{+} \mathrm{RANKL}^{+}(\%)$, and as the means $\pm \mathrm{SD}$ for all other subsets. COPD, chronic obstructive pulmonary disease; RANKL, receptor activator of nuclear factor- $\kappa \mathrm{B}$ ligand; IL-17, interleukin-17.

of $\mathrm{RANKL}^{+} \mathrm{CD}^{+} \mathrm{T}$ cells than the non-smokers $(\mathrm{P}=0.002)$. Importantly, the proportion of $\mathrm{CD}^{+} \mathrm{T}$ cells positive for both RANKL and IL-17 (RANKL ${ }^{+} \mathrm{IL}_{-1} 17^{+} \mathrm{CD} 4^{+} \mathrm{T}$ cells) differed among the 3 groups, and it was higher in the patients with COPD than in the non-smokers $(\mathrm{P}=0.010)$.

To determine whether the increase in the number of RANKL ${ }^{+} \mathrm{IL}-17^{+} \mathrm{CD} 4^{+} \mathrm{T}$ cells was due to increased RANKL expression in Th17 cells, we further analyzed the expression level of RANKL in Th17 cells. However, the percentage of RANKL-expressing Th17 cells (RANKL ${ }^{+}$Th17\%) was similar, with no significant differences between the 3 groups $(\mathrm{P}=0.508)$ as shown in Table III.
Correlation between $T$ cell RANKL expression and clinical parameters. Next, we investigated whether T cell RANKL expression correlated with clinical parameters. The percentage of RANKL ${ }^{+} \mathrm{CD}^{+}{ }^{+} \mathrm{T}$ cells inversely correlated with BMD of the lumbar vertebrae $(\mathrm{P}=0.01, \mathrm{r}=-0.229)$, and that of the femoral neck $(\mathrm{P}<0.001, \mathrm{r}=-0.350)$ (Fig. 4). There was no correlation between the percentage of $\mathrm{RANKL}^{+} \mathrm{CD}^{+} \mathrm{T}$ cells and BMD (lumbar vertebrae and femoral neck; $\mathrm{P}=0.335, \mathrm{P}=0.057$ ), or between the percentage of IL-17 ${ }^{+} \mathrm{RANKL}^{+} \mathrm{CD} 4^{+} \mathrm{T}$ cells and $\mathrm{BMD}$ (lumbar vertebrae and femoral neck; $\mathrm{P}=0.429, \mathrm{P}=0.188$ ).

There were positive correlations between the smoking index and the percentage of RANKL ${ }^{+} \mathrm{CD} 4{ }^{+} \mathrm{T}$ cells $(\mathrm{P}<0.001, \mathrm{r}=0.483)$, 

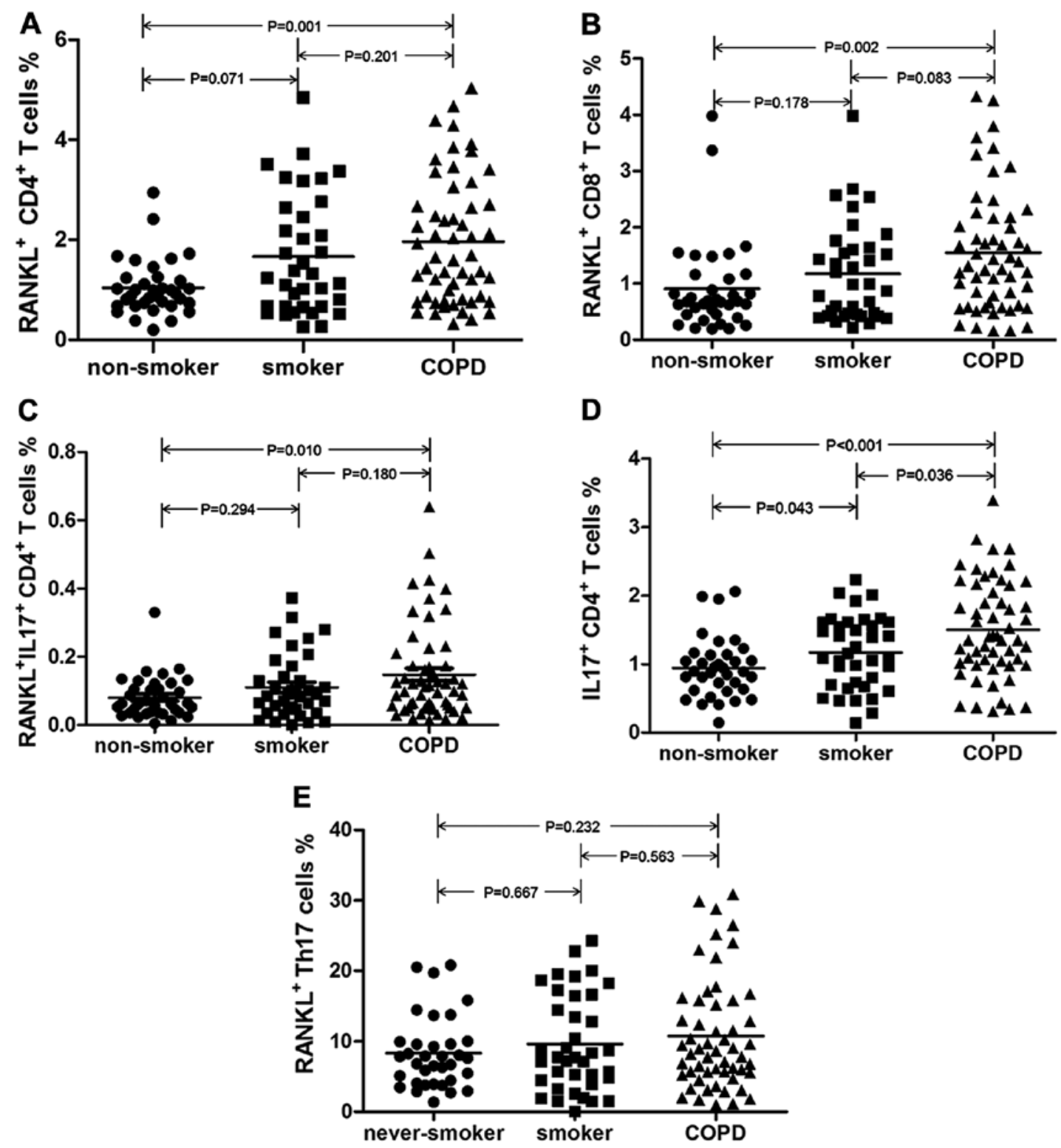

Figure 2. Receptor activator of nuclear factor- $\kappa \mathrm{B}$ ligand $(\mathrm{RANKL})^{+} \mathrm{T}$ cell subsets in the peripheral blood of non-smokers, smokers and patients with chronic obstructive pulmonary disease $\approx(\mathrm{COPD})$. (A) Percentage of RANKL-positive $\mathrm{CD} 4^{+} \mathrm{T}$ cells. (B) The percentage of RANKL-positive CD8 ${ }^{+} \mathrm{T}$ cells. (C) Percentage of RANKL- and interleukin-17 (IL-17) double-positive CD4+ T cells. (D) Percentage of IL-17-positive CD4+ T cells. (E) Percentage of RANKL-positive Th17 cells. (A, D and E) A P-value $<0.05$ was considered to indicate a statistically significant difference. (B and C) A P-value $<0.017$ was considered to indicate a statistically significant difference.

that of RANKL ${ }^{+} \mathrm{CD}^{+} \mathrm{T}$ cells $(\mathrm{P}=0.006, \mathrm{r}=0.312)$, and that of IL-17 ${ }^{+}$RANKL ${ }^{+} \mathrm{CD} 4^{+} \mathrm{T}$ cells $(\mathrm{P}=0.002, \mathrm{r}=0.352)$ (Fig. 5).

There was a negative correlation between the percentage of RANKL ${ }^{+} \mathrm{CD}^{+} \mathrm{T}$ cells and FEV1\% ( $\left.\mathrm{P}=0.006, \mathrm{r}=-0.242\right)$, and between the RANKL ${ }^{+} \mathrm{CD}^{+}{ }^{+} \mathrm{T}$ cells and FEV1\% $(\mathrm{P}=0.047$, $\mathrm{r}=-0.177$ ) (Fig. 6). There was no correlation observed between the percentage of IL-17 $\mathrm{RANKL}^{+} \mathrm{CD} 4^{+} \mathrm{T}$ cells and FEV1\% ( $\mathrm{P}=0.088)$.

Effect of CSE on RANKL expression in T cells. We then wished to investigate whether CSE affects RANKL expression in T cells. For this purpose, we exposed $\mathrm{CD} 4^{+} \mathrm{T}$ cells and $\mathrm{CD} 8^{+} \mathrm{T}$ cells from healthy volunteers in the absence of $\mathrm{CD} 3 / 28$ antibody to various concentrations of CSE. Following culture for 5 days, we found that CSE induced an increase in RANKL expression in the
$\mathrm{CD}^{+} \mathrm{T}$ cells, but not in the $\mathrm{CD} 8^{+} \mathrm{T}$ cells, in a dose-dependent manner. In line with this finding, CSE also induced an increase in IL-17 expression in the $\mathrm{CD}^{+}{ }^{+} \mathrm{T}$ cells (Table IV and Figs. 7 and 8).

\section{Discussion}

Osteoporosis is one of the major comorbidities associated with COPD. As cigarette smoking is a risk factor for both lung injury in COPD and osteoporosis (4), it is intriguing to speculate that the destruction of the lung parenchyma may be associated in some way with the mechanism of the destruction of bone structure. The link between them is most likely systemic inflammation, which in turn results in an imbalance of the bone metabolic regulation system RANK/RANKL/OPG, which tips the balance towards 

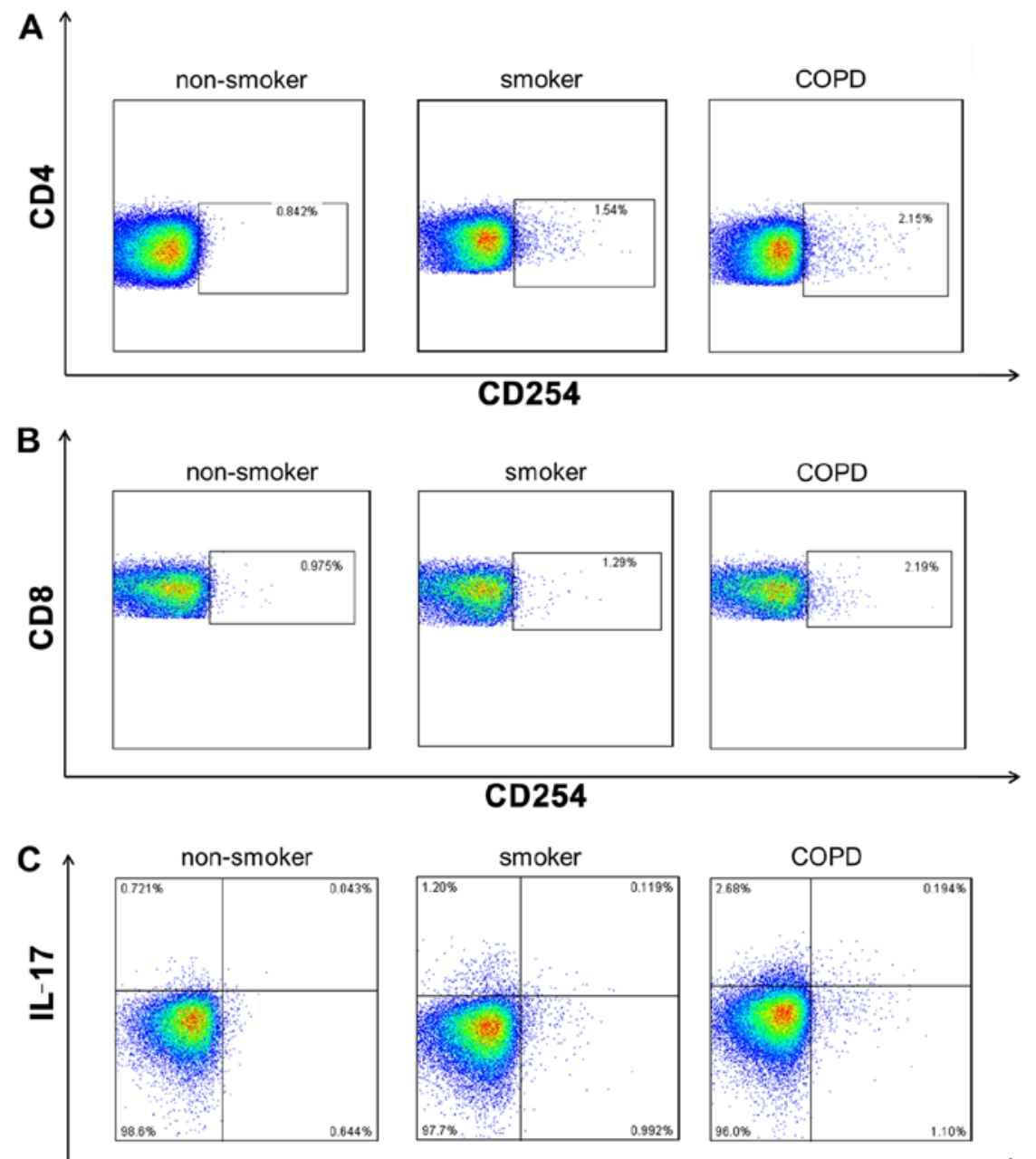

CD254

Figure 3. Flow cytometry scatter plot of receptor activator of nuclear factor- $\mathrm{kB}$ ligand (RANKL) $\mathrm{T}$ cell subsets in the peripheral blood of non-smokers, smokers and patients with chronic obstructive pulmonary disease (COPD). (A) The percentage of RANKL-positive CD4 ${ }^{+} \mathrm{T}$ cells was higher in patients with COPD than in non-smokers. (B) The percentage of RANKL-positive CD8 ${ }^{+} \mathrm{T}$ cells was higher in patients with COPD than in non-smokers. (C) The percentage of RANKLand interleukin-17 (IL-17) double-positive $\mathrm{CD}^{+} \mathrm{T}$ cells (RANKL ${ }^{+} \mathrm{IL}-17^{+} \mathrm{CD} 4^{+} \mathrm{T}$ cell) was higher in patients with COPD than in non-smokers.
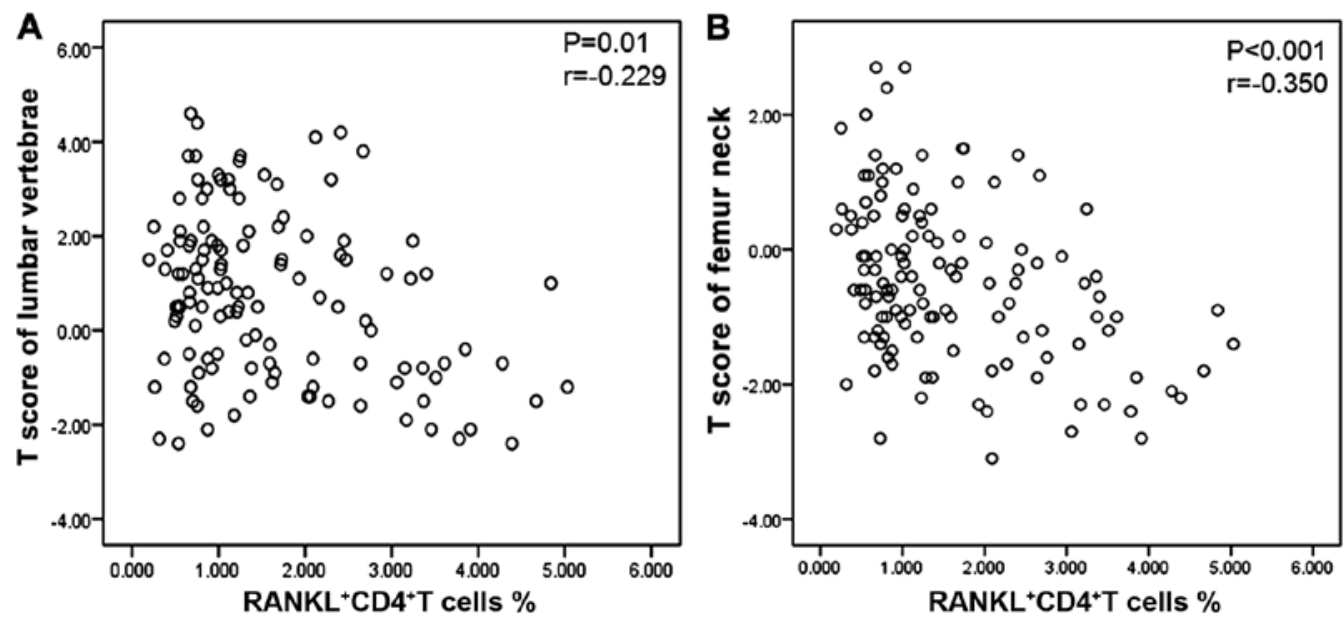

Figure 4. Correlation between $\mathrm{CD} 4{ }^{+} \mathrm{T}$ cell receptor activator of nuclear factor- $\mathrm{\kappa B}$ ligand (RANKL) expression and bone mineral density (BMD). (A) Correlation between the percentage of RANKL ${ }^{+} \mathrm{CD} 4^{+} \mathrm{T}$ cells and BMD of the lumbar vertebrae. (B) Correlation between the percentage of RANKL $\mathrm{RD}^{+} \mathrm{T}$ cells and $\mathrm{BMD}$ of the femur neck. A P-value $<0.05$ was considered to indicate a statistically significant difference.

bone destruction in COPD (5), as evidenced in our previous study (9).
Recent studies have demonstrated that the acquired immunity mediated by $\mathrm{CD} 4^{+} \mathrm{T}$ cells plays an important role in 
Table IV. Effects of CSE on RANKL and IL-17 expression in T cells.

\begin{tabular}{lccccc}
\hline Cell subset & CSE0\% & CSE1\% & CSE1.5\% & CSE2\% & $\begin{array}{c}\text { P-value among } \\
\text { the 4 groups }\end{array}$ \\
\hline RANKL ${ }^{+} \mathrm{CD}^{+} \mathrm{T}$ cell $(\%)$ & $0.87 \pm 0.86$ & $0.98 \pm 0.78$ & $1.16 \pm 0.93$ & $1.17 \pm 0.86$ & 0.006 \\
$\mathrm{RANKL}^{+} \mathrm{CD}^{+} \mathrm{T}$ cell $(\%)$ & $1.20 \pm 1.04$ & $1.35 \pm 0.81$ & $1.80 \pm 1.46$ & $1.64 \pm 1.11$ & 0.106 \\
$\mathrm{IL}-17^{+} \mathrm{CD} 4^{+} \mathrm{T}$ cell $(\%)$ & $0.75 \pm 0.56$ & $0.90 \pm 0.52$ & $0.94 \pm 0.54$ & $1.24 \pm 0.57$ & $<0.001$ \\
\hline
\end{tabular}

Data are presented as the means \pm SD. COPD, chronic obstructive pulmonary disease; RANKL, receptor activator of nuclear factor- $\kappa \mathrm{B}$ ligand; IL-17, interleukin-17; CSE, cigarette smoke extract.
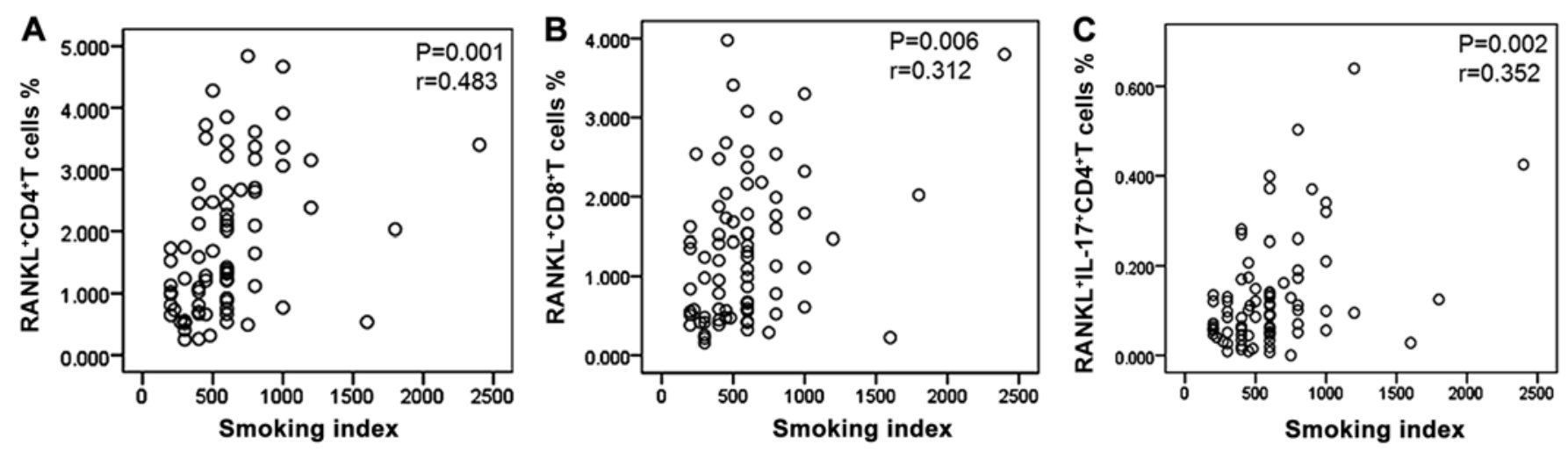

Figure 5. Correlation between $\mathrm{T}$ cell receptor activator of nuclear factor- $\mathrm{\kappa B}$ ligand (RANKL) expression and smoking index. (A) Correlation between the percentage of $\mathrm{RANKL}^{+} \mathrm{CD} 4^{+} \mathrm{T}$ cells and smoking index. (B) Correlation between the percentage of RANKL $\mathrm{CD}^{+} \mathrm{T}$ cells and smoking index. (C) Correlation between RANKL- and interleukin-17 (IL-17) double-positive CD4 ${ }^{+} \mathrm{T}$ cells (RANKL ${ }^{+} \mathrm{IL}-17^{+} \mathrm{CD} 4^{+} \mathrm{T}$ cell) and smoking index. A P-value $<0.05$ was considered to indicate a statistically significant difference.
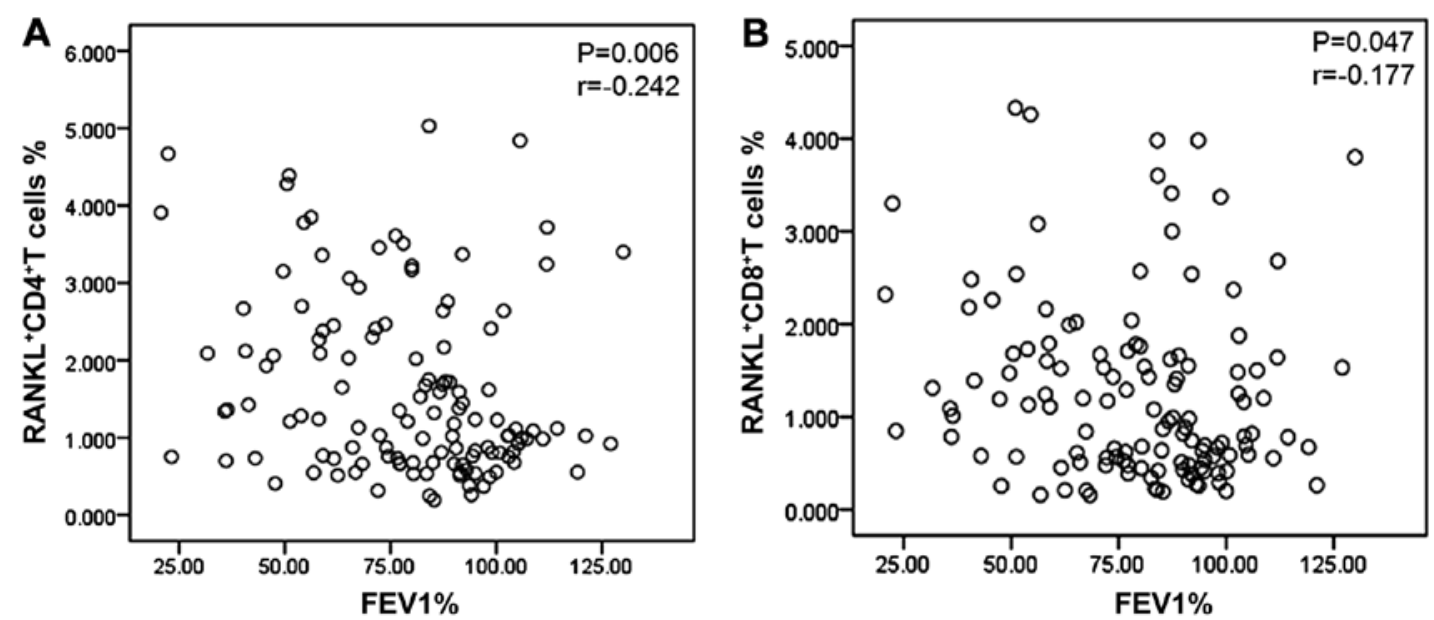

Figure 6. Correlation between $\mathrm{T}$ cell receptor activator of nuclear factor- $\mathrm{kB}$ ligand (RANKL) expression and lung functions. (A) Correlation between the percentage of RANKL ${ }^{+} \mathrm{CD}_{4}^{+} \mathrm{T}$ cells and FEV1\%. (B) Correlation between the percentage of RANKL ${ }^{+} \mathrm{CD}^{+} \mathrm{T}$ cells and FEV1\%. A P-value $<0.05$ was considered to indicate a statistically significant difference.

COPD (23).In animal experiments, emphysema that was caused by smoke exposure, depended on the functional involvement of Th17 cells (IL-17+ $\mathrm{CD}^{+} \mathrm{T}$ cells) and IL-17 $(24,25)$. In patients with COPD, Th17 cells and IL-17 were shown to be increased in the lungs and bronchoalveolar lavage fluid $(26,27)$. Of note, Th17 cells have previously been shown to express high levels of RANKL, and to be actively involved in the process of bone destruction in experimental arthritis (12-16).
In this study, we found for the first time, to the best of our knowledge, that patients with COPD exhibited a higher percentage of RANKL-positive CD4 ${ }^{+} \mathrm{T}$ cells, and more notably, a higher percentage of RANKL- and IL-17 double-positive $\mathrm{CD} 4^{+} \mathrm{T}$ cells (RANKL ${ }^{+} \mathrm{IL}-17^{+} \mathrm{CD} 4^{+} \mathrm{T}$ cells) in their blood, as compared to the healthy non-smoking controls. Importantly, the percentage of $\mathrm{RANKL}^{+} \mathrm{CD} 4^{+} \mathrm{T}$ cells was associated with BMD of the lumbar vertebrae and the femoral neck. 


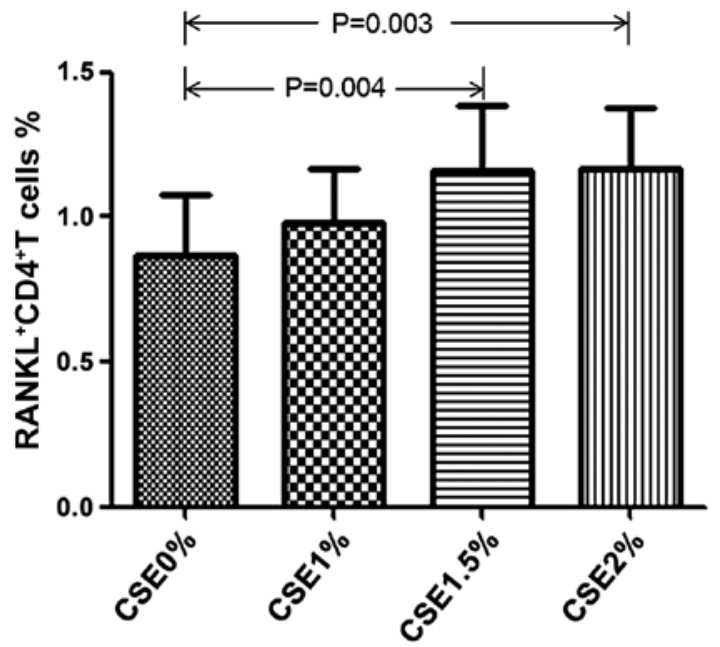

Figure 7. Effect of various concentrations of cigarette smoke extract (CSE) on receptor activator of nuclear factor- $\kappa \mathrm{B}$ ligand (RANKL) expression in $\mathrm{CD}^{+} \mathrm{T}$ cells in vitro. A P-value $<0.05$ was considered to indicate a statistically significant difference.

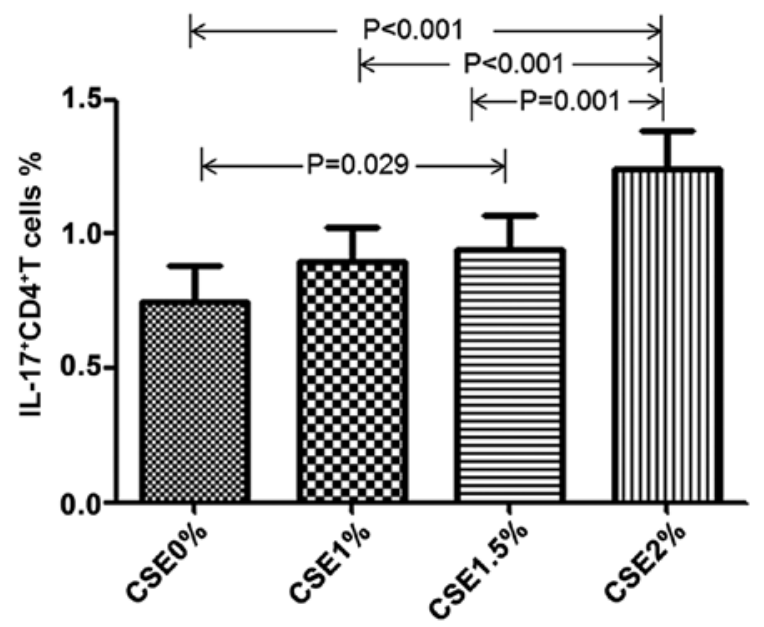

Figure 8. Effect of various concentrations of CSE on interleukin-17 (IL-17) expression in $\mathrm{CD}^{+} \mathrm{T}$ cells in vitro. A P-value $<0.05$ iwas considered to indicate a statistically significant difference.

To determine whether RANKL expression in $\mathrm{CD}^{+}{ }^{+} \mathrm{T}$ cells is associated with exposure to smoke, we revealed that the percentage of $\mathrm{RANKL}^{+} \mathrm{CD} 4^{+} \mathrm{T}$ cells and that of RANKL ${ }^{+} \mathrm{IL}-17^{+} \mathrm{CD} 4^{+} \mathrm{T}$ cells in the peripheral blood positively correlated with the smoking indexes. In vitro experiments also revealed that exposure to CSE increased RANKL expression in $\mathrm{CD}^{+} \mathrm{T}$ cells. We also found an increase in the frequency of Th17 cells, but not an increase in RANKL expression in these cells in the peripheral blood of patients with COPD. These data, together with the effect of CSE on the proliferation of Th17 cells in vitro, suggested that the increased percentage of RANKL ${ }^{+} \mathrm{IL}-$ $17^{+} \mathrm{CD}^{+} \mathrm{T}$ cells among $\mathrm{CD} 4^{+} \mathrm{T}$ cells from patients with $\mathrm{COPD}$ was due to increased numbers of Th17 cells, which may have been as a consequence of exposure to cigarette smoke. Taken together, these findings indicate that by expressing RANKL, $\mathrm{CD}^{+} \mathrm{T}$ cells, and Th17 cells among them, may be involved in the pathogenesis of osteoporosis, acting as the common mechanistic link between lung disease and its major comorbidity osteoporosis.
As mentioned above, $\mathrm{CD} 4^{+} \mathrm{T}$ cells, both Th1 cells and Th17 cells, are found increased in the airways and lungs of smokers with COPD. The same may be true in the peripheral blood in patients with COPD, though only a few studies have examined circulatory $\mathrm{CD} 4^{+} \mathrm{T}$ cells. Majori et al reported an increased percentage of $\mathrm{CD} 4^{+} \mathrm{IFN}-\gamma^{+} \mathrm{T}$ cells in the circulation of patients with COPD (28). In a recent study, an increase in the frequency of circulatory Th17 cells was also observed in patients with COPD, as in Th1 and regulatory T cell subsets (29). Inverse correlations were also found between Th17 cells and FEV1\%. In addition, increases in Th17 cells predicted the presence and severity of airflow limitations (29). The implications of increased $\mathrm{CD}^{+} \mathrm{T}$ cells, including Th17 cells in the circulation still need further study, but it is logical to speculate that these cells may play an important role in the persistence of systemic inflammation. The results of the present study provide evidence of the potential role of these cells in COPD, linking the disease of the distal lung to systemic comorbidities.

$\mathrm{CD}^{+} \mathrm{T}$ cells have long been believed to play a central role in both airway inflammation and lung destruction by producing mediators and enzymes (23). Although the expression of RANKL in $\mathrm{CD}^{+} \mathrm{T}$ cells has been previously confirmed (30), its implication in bone destruction remains controversial. This study demonstrated that the percentage of $\mathrm{RANKL}^{+} \mathrm{CD}^{+} \mathrm{T}$ cells was increased in patients with COPD as compared to healthy non-smokers; however, it did not correlate with BMD. Although the percentage of $\mathrm{RANKL}^{+} \mathrm{CD} 8^{+} \mathrm{T}$ cells weakly correlated with the smoking index, our in vitro experiments failed to show an effect of CSE exposure on RANKL expression in $\mathrm{CD}^{+} \mathrm{T}$ cells. This suggests that although $\mathrm{CD}^{+} \mathrm{T}$ cells are key players in lung disease, they may not be involved in bone disease in COPD. An earlier study by Choi et al showed that, while $\mathrm{CD}^{+} \mathrm{T}$ cells induced osteoclast differentiation in the presence of $\mathrm{M}-\mathrm{CSF}, \mathrm{CD} 8^{+} \mathrm{T}$ cells did not. On the contrary, in the presence of M-CSF and sRANKL, $\mathrm{CD}^{+} \mathrm{T}$ cells suppressed osteoclastogenesis (30). Apparently, the implication of peripheral $\mathrm{RANKL}^{+} \mathrm{CD}^{+} \mathrm{T}$ cells in patients with COPD warrants further investigation.

The present study has several limitations. Although a correlation between RANKL expression in $\mathrm{CD}^{+}{ }^{+} \mathrm{T}$ cells and BMD was observed, the r-values (i.e., correlation index) were small $(-0.229$ and -0.35$)$, suggesting that $\mathrm{RANKL}^{+} \mathrm{CD}^{+} \mathrm{T}$ cells may only have a partial effect on BMD decrease in COPD, and other important mechanisms are thus likely to be involved. In addition, we failed to reveal a correlation between an increased number RANKL ${ }^{+} \mathrm{IL}-17^{+} \mathrm{CD} 4^{+} \mathrm{T}$ cells and BMD, which may be explained by the relatively small increase in the number of Th17 cells in COPD, and the very low percentage of RANKL ${ }^{+} \mathrm{IL}-17^{+} \mathrm{CD} 4^{+} \mathrm{T}$ cells in the peripheral blood, although this lack of correlation does not necessarily exclude the potential role of these cells in bone destruction. Further studies using animal models of COPD with exposure to cigarette smoke are required in order to formally demonstrate a role for Th17 cells in bone loss.

In conclusion, this study demonstrated that the percentages of RANKL ${ }^{+} \mathrm{CD}^{+}{ }^{+} \mathrm{T}$ cells and RANKL- and IL-17 doublepositive $\mathrm{CD}^{+} \mathrm{T}$ cells were increased in the peripheral blood of patients with COPD. The percentage of $\mathrm{RANKL}{ }^{+} \mathrm{CD} 4^{+} \mathrm{T}$ cells was associated with bone loss, which provided evidence of the potential role of these adaptive immune cells in osteoporosis. 
Further studies on the common pathways that may lead to lung destruction and bone loss in both patients and animal models that are exposed to environmental smoke would perhaps provide more informative insight into the pathogenesis of COPD and its associated comorbidities.

\section{Acknowledgements}

This study was supported by the National Natural Science Foundation of China (no. 81170039) and the Natural Science Foundation of Beijing (no. 7152037).

\section{References}

1. Committee GE: Global strategy for the diagnosis, management, and prevention of chronic obstructive pulmonary disease. (Revised 2011).

2. Incalzi RA, Caradonna P, Ranieri P, Basso S, Fuso L, Pagano F, Ciappi G and Pistelli R: Correlates of osteoporosis in chronic obstructive pulmonary disease. Respir Med 94: 1079-1084, 2000.

3. Katsura $\mathrm{H}$ and Kida $\mathrm{K}$ : A comparison of bone mineral density in elderly female patients with COPD and bronchial asthma. Chest 122: 1949-1955, 2002.

4. Bon J, Fuhrman CR, Weissfeld JL, Duncan SR, Branch RA, Chang CC, Zhang Y, Leader JK, Gur D, Greenspan SL and Sciurba FC: Radiographic emphysema predicts low bone mineral density in a tobacco-exposed cohort. Am J Respir Crit Care Med 183: 885-890, 2011.

5. Lehouck A, Boonen S, Decramer M and Janssens W: COPD, bone metabolism, and osteoporosis. Chest 139: 648-657, 2011.

6. Boyce BF and Xing L: The RANKL/RANK/OPG pathway. Curr Osteoporos Rep 5: 98-104, 2007.

7. Lacey DL, Timms E, Tan HL, Kelley MJ, Dunstan CR, Burgess T, Elliott R, Colombero A, Elliott G, Scully S, et al: Osteoprotegerin ligand is a cytokine that regulates osteoclast differentiation and activation. Cell 93: 165-176, 1998.

8. Väänänen HK and Laitala-Leinonen T: Osteoclast lineage and function. Arch Biochem Biophys 473: 132-138, 2008.

9. Bai P, Sun Y, Jin J,Hou J, Li R, Zhang Q and Wang Y: Disturbance of the OPG/RANK/RANKL pathway and systemic inflammation in COPD patients with emphysema and osteoporosis. Respir Res 12: 157, 2011

10. Pobeha P, Petrasova D, Tkacova R and Joppa P: Circulatory osteoprotegerin is related to osteoporosis of the hip in patients with COPD. Respir Med 108: 621-627, 2014.

11. Rifas L, Arackal S and Weitzmann MN: Inflammatory T cells rapidly induce differentiation of human bone marrow stromal cells into mature osteoblasts. J Cell Biochem 88: 650-659, 2003.

12. Kong YY, Feige U, Sarosi I, Bolon B, Tafuri A, Morony S, Capparelli C, Li J, Elliott R, McCabe S, et al: Activated T cells regulate bone loss and joint destruction in adjuvant arthritis through osteoprotegerin ligand. Nature 402: 304-309, 1999.

13. Kotake S, Udagawa N, Hakoda M, Mogi M, Yano K, Tsuda E, Takahashi K, Furuya T, Ishiyama S, Kim KJ, et al: Activated human $\mathrm{T}$ cells directly induce osteoclastogenesis from human monocytes: Possible role of $T$ cells in bone destruction in rheumatoid arthritis patients. Arthritis Rheum 44: 1003-1012, 2001.

14. Miranda-Carús ME, Benito-Miguel M, Balsa A, Cobo-Ibáñez T, Pérez de Ayala C, Pascual-Salcedo D and Martín-Mola E: Peripheral blood T lymphocytes from patients with early rheumatoid arthritis express RANKL and interleukin-15 on the cell surface and promote osteoclastogenesis in autologous monocytes. Arthritis Rheum 54: 1151-1164, 2006.
15. Sato K, Suematsu A, Okamoto K, Yamaguchi A, Morishita Y, Kadono Y, Tanaka S, Kodama T, Akira S, Iwakura Y, et al: Th17 functions as an osteoclastogenic helper T cell subset that links T cell activation and bone destruction. J Exp Med 203: 2673-2682, 2006.

16. Kikuta J, Wada Y, Kowada T, Wang Z, Sun-Wada GH, Nishiyama I, Mizukami S, Maiya N, Yasuda H, Kumanogoh A, et al: Dynamic visualization of RANKL and Th17-mediated osteoclast function. J Clin Invest 123: 866-873, 2013.

17. Sullivan AK, Simonian PL, Falta MT, Mitchell JD, Cosgrove GP, Brown KK, Kotzin BL, Voelkel NF and Fontenot AP: Oligoclonal $\mathrm{CD}^{+} \mathrm{T}$ cells in the lungs of patients with severe emphysema. Am J Respir Crit Care Med 172: 590-596, 2005.

18. Maeno T, Houghton AM, Quintero PA, Grumelli S, Owen CA and Shapiro SD: $\mathrm{CD} 8^{+} \mathrm{T}$ cells are required for inflammation and destruction in cigarette smoke-induced emphysema in mice. J Immunol 178: 8090-8096, 2007.

19. Doe C, Bafadhel M, Siddiqui S, Desai D, Mistry V, Rugman P, McCormick M, Woods J, May R, Sleeman MA, et al: Expression of the Thelper 17-associated cytokines IL-17A and IL-17F in asthma and COPD. Chest 138: 1140-1147, 2010.

20. Vestbo J, Hurd SS, Agustí AG, Jones PW, Vogelmeier C, Anzueto A, Barnes PJ, Fabbri LM, Martinez FJ, Nishimura M, et al: Global strategy for the diagnosis, management, and prevention of chronic obstructive pulmonary disease: GOLD executive summary. Am J Respir Crit Care Med 187: 347-365, 2013.

21. Hou J, Sun Y, Hao Y, Zhuo J, Liu X, Bai P, Han J, Zheng X and Zeng H: Imbalance between subpopulations of regulatory $\mathrm{T}$ cells in COPD. Thorax 68: 1131-1139, 2013.

22. Oltmanns U, Chung KF, Walters M, John M and Mitchell JA: Cigarette smoke induces IL-8, but inhibits eotaxin and RANTES release from airway smooth muscle. Respir Res 6: 74, 2005.

23. Brusselle GG, Joos GF and Bracke KR: New insights into the immunology of chronic obstructive pulmonary disease. Lancet 378: 1015-1026, 2011.

24. Chen K, Pociask DA, McAleer JP, Chan YR, Alcorn JF, Kreindler JL, Keyser MR, Shapiro SD, Houghton AM, Kolls JK and Zheng M: IL-17RA is required for CCL2 expression, macrophage recruitment, and emphysema in response to cigarette smoke. PLoS One 6: e20333, 2011.

25. Shan M, Yuan X, Song LZ, Roberts L, Zarinkamar N, Seryshev A, Zhang Y, Hilsenbeck S, Chang SH, Dong C, et al: Cigarette smoke induction of osteopontin (SPP1) mediates $\mathrm{T}(\mathrm{H}) 17$ inflammation in human and experimental emphysema. Sci Transl Med 4: 117ra9, 2012.

26. Eustace A, Smyth LJ, Mitchell L, Williamson K, Plumb J and Singh D: Identification of cells expressing IL-17A and IL-17F in the lungs of patients with COPD. Chest 139: 1089-1100, 2011.

27. Zhang J, Chu S, Zhong X, Lao Q, He Z and Liang Y: Increased expression of $\mathrm{CD} 4^{+} \mathrm{IL}-17^{+}$cells in the lung tissue of patients with stable chronic obstructive pulmonary disease (COPD) and smokers. Int Immunopharmacol 15: 58-66, 2013

28. Majori M, Corradi M, Caminati A, Cacciani G, Bertacco S and Pesci A: Predominant TH1 cytokine pattern in peripheral blood from subjects with chronic obstructive pulmonary disease. J Allergy Clin Immunol 103: 458-462, 1999.

29. Vargas-Rojas MI, Ramírez-Venegas A, Limón-Camacho L, Ochoa L, Hernández-Zenteno R and Sansores RH: Increase of Th17 cells in peripheral blood of patients with chronic obstructive pulmonary disease. Respir Med 105: 1648-1654, 2011.

30. Choi Y, Woo KM, Ko SH, Lee YJ, Park SJ, Kim HM and Kwon BS: Osteoclastogenesis is enhanced by activated B cells but suppressed by activated CD8(+) T cells. Eur J Immunol 31: 2179-2188, 2001 . 